\title{
MEDIASI PENAL DALAM PENANGANAN PELAKU TINDAK PIDANA SEBAGAI UPAYA MEMINIMALISIR KELEBIHAN HUNIAN DI LEMBAGA PEMASYARAKATAN
}

\author{
July Esther', Bintang ME Naibaho², Bintang Christine ${ }^{3}$ \\ Program Studi Magister Hukum \\ Program Pascasarjana \\ Universitas HKBP Nommensen, Medan-Sumatera Utara-Indonesia \\ e-mail: julyesther@uhn.ac.id
}

\begin{abstract}
The excess housing in the Indonesian Correctional Institution does not abate. This condition is faced with criminal efforts which should be a final diversion related to the effort to include convicted persons in Corrections Institutions. The aim is to analyze whether the mediation of penal as the application of Restorative Justice can be an alternative effort to minimize excess occupancy inmates in correctional institutions. The use of this research as a recommendation for law enforcement officials in the handling of criminal acts by promoting penal mediation. The research uses normative legal research methods with literature studies. Mediation Penal is considered able to be an intermediary process of mediation or peace between perpetrators of criminal acts with victims of criminal acts as minimizing the excess occupancy that starts from handling the police and prosecutors stage.

Keywords: Penal Mediation; Excessive Occupancy.
\end{abstract}

\begin{abstract}
Abstrak
Kelebihan hunian di Lembaga Pemasyarakatan Indonesia tak kunjung reda. Kondisi ini diperhadapkan pada upaya pemidanaan yang seyogyanya menjadi sebuah ultimum remedium dalam upaya memasukkan terpidana dalam Lembaga Pemasyarakatan. Penelitian ini tujuannya adalah untuk menganalisis mediasi penal sebagai penerapan restorative justice dapat menjadi alternatif upaya meminimalisir kelebihan hunian narapidana di lembaga pemasyarakatan. Kegunaan penelitian ini sebagai rekomendasi bagi para penegak hukum dalam penanganan "pelaku tindak pidana" yang mengedepankan mediasi penal. Penelitian ini menggunakan metode penelitian hukum normatif dengan studi kepustakaan. Mediasi Penal dianggap mampu untuk menjadi penengah dalam penanganan tindak pidana dan penyelesaian hukum antara korban dengan pelaku tindak pidana untuk meminimalisir kelebihan hunian yang dimulai dari penanganan tahap kepolisian maupun kejaksaan.

Kata kunci: Mediasi Penal; Kelebihan Hunian.
\end{abstract}

\section{A. Pendahuluan}

Restorative Justice dalam hukum pidana menekankan kejahatan sebagai tindakan yang melawan individu atau masyarakat bukan sebagai bentuk pelanggaran kepada Negara. Korban memainkan peran utama dan menerima restitusi dari pelaku kejahatan. Restorative Justice memandang korban yang menderita luka atau kehilangan nyawa akibat perbuatan pidana dari pelaku tindak pidana, tidak akan mungkin dapat diganti oleh penjatuhan pidana kepada pelaku tindak pidana oleh Negara tanpa adanya kompensasi yang diserahkan ke korban. 
Restorative Justice memerlukan aksi riil restorasi kemanusiaan oleh pelaku kejahatan dalam wujud perbaikan bagi keluarga korban berupa santunan kemanusiaan yang melambangkan secara ikhlas dan sikap tobat serta minta maaf kepada korban atau keluarga korban. ${ }^{1}$

Hukum pidana itu sendiri menurut Bambang Waluyo berisikan peraturan-peraturan tentang:

1. Perbuatan yang dapat diancam dengan hukuman (Strafbare feiten) misalnya:

a. Mengambil barang milik orang lain ;

b. Dengan sengaja merampas nyawa orang lain.

2. Siapa-siapa yang dapat dihukum atau dengan perkataan lain mengatur pertanggungan jawab terhadap hukum pidana

3. Hukuman apa yang dapat dijatuhkan terhadap orang yang melakukan perbuatan yang bertentangan dengan undang-undang atau juga disebut hukum penintentier. ${ }^{2}$

Penegak hukum dalam menjalankan fungsinya sering mengalami kewalahan dikarenakan kondisi masyarakat dewasa ini semakin kompleks, maka perbuatan pidana yang terjadi dalam masyarakat semakin beragam kemudian diapit oleh sebuah sistem yang merupakan suatu keharusan yang wajib hukumnya dalam memakai aturan hukum positif dengan stigma pemikiran logis Negara Republik Indonesia bahwa "hukum yang baik adalah segala peraturan yang sifatnya tertulis" sehingga setiap pokok permasalahannya akan dilarikan kembali kepada konsep yang sudah terkodifikasikan tanpa harus melihat setiap kepentingan, hal apa yang di langgar serta benar tidak benar yang lazim dilambangkan dengan "Neraca Keadilan" menuntut menerima bagian yang sama pula.

Keadilan menurut Subekti berasal dari Tuhan Yang Maha Esa tetapi manusia diberikan kecakapan atau kemampuan untuk meraba atau merasakan keadaan yang dinamakan adil itu. ${ }^{3}$ Salah satu kelemahan "sistem peradilan pidana" adalah tidak adanya peran serta partisipasi korban dan pelaku secara langsung dalam menyelesaikan perkara. Oleh sebab itu sering kali dianggap tidak mewakili aspirasi korban dan sanksi pidana yang dijatuhkan juga dianggap tidak memberikan keuntungan yang dapat dirasakan secara langsung baik oleh korban maupun pelaku.

Menurut Jim Consedine sebagaimana dikutip oleh DS. Dewi dan Fatahillah A. Syukur mendefinisikan keadilan restoratif sebagai berikut: "Tindak kriminal tidak lagi dianggap sebagai serangan terhadap negara, tapi kejahatan yang dilakukan seseorang terhadap orang lain. Keadilan restoratif berlandaskan pada kemanusiaan kedua belah pihak, pelaku dan korban. Proses restoratif bertujuan untuk memulihkan luka semua pihak yang disebabkan oleh kejahatan yang dilakukan. Alternatif solusi dieksplorasi dengan berfokus untuk memperbaiki kerusakan yang ditimbulkan". ${ }^{4}$

Definisi restorative justice yang lain dikemukakan oleh Braithwaite sebagaimana dikutip oleh DS. Dewi dan Fatahillah A. Syukur menyatakan bahwa keadilan restoratif mendorong reintegrasi dan menghindari stigmatisasi; memelihara rasa tanggung jawab, penyesalan, restitusi, dan pemaafan; dan menolak hukuman penjara dan bentuk pengasingan lain. Keterlibatan masyarakat secara aktif merupakan cara pandang restorative justice menuntut usaha kerja sama antara masyarakat dan pemerintah untuk menciptakan suatu lingkungan di mana korban dan pelaku dapat melakukan rekonsiliasi konflik dan menyelesaikan kerugian

\footnotetext{
${ }^{1}$ Trisno Raharjo, Mediasi Pidana dalam Sistem Peradilan Pidana-Suata Kajian Perbandingan dan Penerapannya di Indonesia, (Yogyakarta: Buku Litera, 2011), 25-26.

${ }^{2}$ Bambang Waluyo, Pidana dan Pemidanaan, (Jakarta: Sinar Grafika, 2008), 6-7.

${ }^{3}$ Ibid, 41

${ }^{4}$ DS. Dewi dan Fatahillah A. Syukur, Mediasi Penal: Penerapan Restorative Justice di Pengadilan Anak Indonesia, (Depok: Indie Pro Publishing, 2011), 29.
} 
http://ejournal.uhn.ac.id/index.php/opinion

yang timbul, dan dalam waktu bersamaan menimbulkan rasa aman dalam masyarakat itu sendiri. $^{5}$

Salah satu bentuk restorative justice adalah mediasi penal. Menurut Barda Nawawi Arief bahwa alasan dipergunakan Mediasi Penal dalam penyelesaian perkara pidana adalah karena ide dari Mediasi Penal berkaitan dengan masalah pembaharuan hukum pidana (Penal Reform), berkaitan juga dengan masalah pragmatisme, alasan lainnya adalah adanya ide perlindungan korban, ide harmonisasi, ide Restorative Justice, ide mengatasi kelakuan (formalitas) dan efek negatif dari sistem peradilan pidana dan sistem pemidanaan yang berlaku, serta upaya pencarian upaya alternatif pemidanaan (selain penjara). ${ }^{6}$

Berdasarkan latar belakang masalah yang telah diuraikan diatas maka peneliti tertarik untuk mengangkat permasalahan yang menjadi rumusan masalah adalah Apakah Mediasi Penal Sebagai Penerapan Restorative Justice Dapat Menjadi Alternatif Upaya Meminimalisir Kelebihan Hunian (Over Capacity) Narapidana di Lembaga Pemasyarakatan? Sebagai tujuan dari penelitian ini adalah untuk menganalisis Mediasi Penal Sebagai Penerapan Restorative Justice Sebagai Alternatif Meminimalisir Kelebihan Hunian Narapidana di Lembaga Pemasyarakatan.

\section{B. Metode Penelitian}

Penelitian ini menggunakan metode studi kepustakaan yang merupakan penelitian hukum normatif dengan melakukan kajian literatur berupa buku-buku teks, peraturan perundang-undangan, dan hasil penelitian para peneliti sebelumnya yang merupakan bagian dari sumber bahan hukum. Metode pendekatan masalah yang digunakan adalah pendekatan konseptual, pendekatan perundang-undaangan, dan pendekatan kasus. Teknik pengumpulan data sebagai sumber bahan hukum diperoleh dari beberapa lembaga pemasyarakatan di wilayah Sumatera Utara, kemudian mengumpulkan literatur berupa buku-buku teks, peraturan perundang-undangan dan hasil penelitian yang berkaitan dengan kelebihan hunian dalam lembaga pemasyarakatan. Sumber bahan hukum yang terkumpul dianalisis secara sistematis dan tersusun untuk dibahas secara teoritis dan kritis sehingga mendapatkan kesimpulan dan rekomendasi dari hasil penelitian ini.

\section{Pembahasan}

\section{Tinjauan Umum tentang Mediasi Penal}

Sebelum membahas mengenai mediasi penal maka akan dikaji pengertian dari mediasi. Mediasi berasal dari bahasa Latin, mediare yang berarti "berada di tengah". Pengertian yang lebih sederhana mediasi penal adalah penyelesaian perkara pidana melalui musyawarah dengan bantuan mediator yang netral, dihadiri korban dan pelaku beserta orang tua dan perwakilan masyarakat, dengan tujuan pemulihan bagi korban, pelaku, dan lingkungan, ${ }^{7}$ sedangkan pengertian mediasi menurut Peraturan Mahkamah Agung Nomor 1 Tahun 2008 adalah cara penyelesaian sengketa melalui proses perundingan untuk mencapai kesepakatan para pihak dengan dibantu mediator.

Barda Nawawi Arief menyatakan bahwa "mediasi penal merupakan salah satu bentuk alternatif penyelesaian sengketa di luar pengadilan, ini pada umumnya digunakan di lingkungan kasus-kasus perdata, tidak untuk kasus-kasus pidana. Berdasarkan perundangundangan yang berlaku di Indonesia saat ini (hukum positif) pada prinsipnya kasus pidana

\footnotetext{
${ }^{5}$ Ibid, 31.

${ }^{6}$ Barda Nawawi Arif, Kebijakan Legislatif Dalam Penanggulangan Kejahatan dengan Pidana Penjara, (Semarang: Badan Penerbit Universitas Diponegoro Semarang, 2000), 169-171.

${ }^{7}$ DS. Dewi dan Fatahillah A. Syukur, Op.cit., 86.
} 
tidak dapat diselesaikan di luar pengadilan." ${ }^{8}$ Pada perspektif filosofis, mediasi penal menerapkan asas "menang-menang" (win-win) dan bukan berakhir dengan situasi "kalah-kalah" (lost-lost) atau "menang-kalah" (win-lost) sebagaimana ingin dicapai oleh peradilan dengan pencapaian keadilan formal melalui proses hukum litigasi (law enforcement process).

Selanjutnya Bayu Ardian Aminullah dan Barda Nawawi Arief ${ }^{9}$ menyatakan bahwa mediasi penal merupakan salah satu bentuk Alternative Dispute Resolution (ADR) yaitu penyelesaian perkara pidana di luar pengadilan. ADR salah satunya mediasi penal merupakan cara penyelesaian perkara pidana, sedangkan pendekatan yang digunakan adalah pendekatan keadilan restoratif (restorative justice) yang menekankan adanya perhatian terhadap kondisi korban dan pelaku tindak pidana untuk sebisa mungkin tidak dikenakan sanksi pidana.

Selain itu, Lilik Mulyadi menyatakan bahwa "melalui mediasi penal ini akan mempunyai implikasi bersifat positif ketika secara filosofis dicapainya peradilan dilakukan secara cepat, sederhana, dan biaya ringan karena pihak yang terlibat relatif lebih sedikit dibandingkan melalui proses peradilan dengan komponen Sistem Peradilan Pidana (SPP)." ${ }^{10}$ Melalui proses mediasi penal akan diperoleh keadilan para pihak yang terlibat dalam perkara pidana tersebut yaitu antara pihak pelaku dan korban. Para pihak yaitu korban dan pelaku diharapkan dapat memperoleh alternatif ataupun jalan keluar terbaik menyelesaikan konflik atas perkara yang terjadi. Pencapaian kesepakatan berupa keadilan diantara para pihak tersebut maka korban dan pelaku tindak pidana dapat mengajukan kompensasi untuk ditawarkan yang akhirnya akan dirundingkan dan disepakati bersama sebagai bentuk sifat win-win.

Selanjutnya Lilik Mulyadi menyatakan bahwa "implikasi lain sebenarnya eksistensi mediasi penal dapat dikatakan antara "ada" dan "tiada".Dengan demikian, menjadi menarik apabila lebih lanjut dikaji dimensi, "bagaimana mediasi penal dalam sistem peradilan pidana Indonesia, khususnya dari perspektif asas, teori, norma dan praktik" sehingga diharapkan adanya pemahaman bersifat komprehensif yang berguna bagi kebijakan legislasi, kebijakan aplikatif dan kebijakan administratif dalam merumuskan formulasi norma mediasi penal masa mendatang (ius constituendum).”

Barda Nawawi Arief berpandangan bahwa "adanya penyelesaian kasus pidana di luar pengadilan, terlihat dari perkembangan kongres PBB ke-9/1955 yang berkaitan dengan manajemen peradilan pidana (yaitu dokumen A/CONF.169/6) dikatankan perlunya semua negara mempertimbangkan "privatizing some law enforcement and justice functions" dan "alternative dispute resolution/ADR" (berupa mediasi, konsiliasi, restitusi, dan kompensasi) dalam sistem peradilan pidana khususnya mengenai ADR." ${ }^{2}$

\section{Pemidanaan dan Lembaga Pemasyarakatan}

Andi Hamzah secara tegas memberi pengertian pemidanaan adalah "Penghukuman itu berasal dari kata dasar hukum, sehingga dapat diartikan sebagai menetapkan hukum atau memutuskan tentang hukumnya (berechten)." Janpatar Simamora dan Bintang ME Naibaho mengemukakan bahwa As a consequence of the adoption of a state of law for the Indonesian nation, all state and government activities must truly refer to existing legal rules. The emergence of ideas and thoughts of the rule of law is inseparable from the pattern of implementing state

\footnotetext{
${ }^{8}$ Barda Nawawi Arief, Mediasi Penal Penyelesaian Perkara Pidana Di Luar Pengadilan, (Semarang: Pustaka Magister, 2012), 21.

${ }^{9}$ Bayu Ardian Aminullah dan Barda Nawawi Arief, "Penerapan Mediasi Penal Dengan Pendekatan Restorative Justice Dalam Upaya Penanggulangan Kejahatan Di Indonesia”, Jurnal Meta-Yuridis Vol 3, No 1, 2020: 71-86.

${ }^{10}$ Lilik Mulyadi, Mediasi Penal Dalam Sistem Peradilan Pidana Indonesia, (Bandung: Alumni, 2015), 19.

${ }^{11}$ Ibid, 14-15.

${ }^{12}$ Barda Nawawi Arief, Op.cit., 11.

${ }^{13}$ Tohib Setiady, Pokok-Pokok Hukum Penitensier Indonesia, (Jakarta: Alfabeta, 2010), 21.
} 
Jurnal Magister Hukum Program Pascasarjana Universitas HKBP Nommensen

Volume or Nomor o1 Juli 2020 Halaman. 27-37 e-ISSN: 2723-164X p-ISSN: 2722-9858

http://ejournal.uhn.ac.id/index.php/opinion

power that is vulnerable to arbitrary acts, so it is necessary to limit state power through legal instruments. ${ }^{14}$

Keseluruhan konsep hukum yang telah diatur sedemikian rupa kini dianggap sangat tidak relevan. Kebijakan peradilan hukuman pidana telah berdampak pada pertumbuhan populasi penjara dan kepadatan penjara di hampir seluruh lembaga pemasyarakatan tanah air. Pengadilan di banyak negara saat ini lebih cenderung memberikan hukuman penjara pada pelaku pelanggaran dan menjatuhkan hukuman lebih lama daripada yang mereka lakukan satu dekade yang lalu. Alternatif non penahanan berbasis masyarakat sering diabaikan demi perampasan kebebasan.

Menurut Raden Muhammad Rizki Hidayatullah ${ }^{15}$ bahwa sistem peradilan hukum pidana Indonesia secara luas telah mengenal dan mengatur hukuman dalam berbagai peraturan perundang-undangan dimana setiap orang yang melanggar undang-undang sebagian besar selalu bermuara pada pidana penjara. Hal tersebut dinilai hukuman yang paling praktis bagi sebagian aparat penegak hukum karena pelaku dimasukkan ke dalam Lembaga Pemasyarakatan kemudian menjalani masa hukuman pidananya di sana. Secara tidak langsung hal tersebut merupakan faktor utama yang menyebabkan padatnya penghuni di suatu lembaga pemasyarakatan.

Lembaga Pemasyarakatan adalah suatu tempat di mana seseorang yang dituduh melakukan tindakan kejahatan yang telah terbukti kesalahannya, dan hakim telah menetapkan hukuman berdasarkan keputusan pengadilan yang mempunyai kekuatan hukum yang tetap maka orang tersebut diwajibkan untuk menjalani masa hukumannya di dalam Lembaga Pemasyarakatan. ${ }^{16}$ Lembaga Pemasyarakatan tempat dikumpulkannya manusia yang melanggar aturan dan norma-norma yang ada dalam masyarakat.

Asas yang dianut Lembaga Pemasyarakatan adalah memposisikan tahanan sebagai subyek yang dipandang sebagai pribadi, warga negara biasa, dan sebagai makhluk Tuhan. Oleh karena itu di dalam lembaga pemasyarakatan narapidana mendapat bimbingan dan pembinaan dengan harapan setelah selesai menjalani hukuman, narapidana dapat bersosialisasi dengan masyarakat serta dapat meningkatkan keterampilan agar mampu hidup mandiri di masyarakat. ${ }^{17}$

R.Ahmad Soemadi Praja dan Romli Atmasasmita memberikan pandangan bahwa terdapat 5 prinsip pemasyarakatan sebagai pedoman melaksanakan pembinaan narapidana, yaitu sebagai berikut :

1. Ayomi dan berikan bekal hidup agar mereka dapat menjalankan perannya sebagai yang baik dan berguna;

2. Penjatuhan pidana tidak lagi didasari oleh latar belakang pembalasan. Ini berarti tidak boleh ada penyiksaan terhadap narapidana dan anak didik pada umumnya, baik yang berupa tindakan, perlakuan, ucapan, cara perawatan ataupun penempatan. Satu-satunya derita yang dialami oleh narapidana dan anak didik, hanya dibatasi kemerdekaanya bergerak dalam masyarakat bebas;

\footnotetext{
${ }^{14}$ Janpatar Simamora dan Bintang ME Naibaho, Statutory of The Republic of Indonesia Witness As a Government Institution Implementing Country's Power in The Indonesian State Concerns System, Proceedings of the First Nommensen International Conference on Creativity \& Technology, NICCT, 20-21 September 2019, Medan, North Sumatera, Indonesia, hlm. 3 .

${ }^{15}$ Raden Muhammad Rizki Hidayatullah, "Faktor Penyebab Dan Upaya Penyelesaian Permasalahan Kepadatan Penghuni Lembaga Pemasyarakatan Di Indonesia”, Borneo Law Review Journal Volume 4 No. 1, 2020: 1-20.

${ }^{16}$ Satjipto Rahardjo, Bunga Rampai Permasalahan Dalam Sistem Peradilan Pidana, (Jakarta: Pusat Pelayanan Keadilan dan Pengabdian Hukum, 1998), 17.

${ }^{17}$ Ibid, 18.
} 
http://ejournal.uhn.ac.id/index.php/opinion

3. Berikan bimbingan (bukannya penyiksaan) supaya mereka bertobat. Berikan kepada mereka pengertian mengenai norma-norma hidup dan kegiatan-kegiatan sosial untuk menumbuhkan rasa hidup kemasyarakatannya;

4. Negara tidak berhak membuat mereka menjadi lebih buruk atau lebih jahat daripada sebelum dijatuhi pidana. Salah satu cara diantaranya adalah agar tidak mencampurbaurkan narapidana dengan anak didik, yang melakukan tindak pidana berat dengan yang ringan dan sebagainya;

5. Selama kehilangan (dibatasi) kemerdekaan bergeraknya para narapidana dan anak didik tidak boleh diasingkan dari masyarakat. Perlu ada kontak dengan masyarakat yang terjelma dalam bentuk kunjungan liburan ke Lembaga Pemasyarakatan dan Rumah Tahanan oleh anggota masyarakat bebas dan kesempatan untuk berkumpul bersama sahabat dan keluarganya. $^{18}$

Kondisi jumlah narapidana yang menghuni di Lembaga Pemasyarakatan (Lapas) Sumatera Utara berdasarkan sumber data dari Sistem Database Pemasyarakatan sampai dengan tanggal 16 Agustus 2019 telah mencapai 34.439 orang, yang mana jumlah itu sangat jauh dibandingkan daya tampung Lapas berkapasitas maksimal 12.785 orang, dengan kata lain telah terjadi over kapasitas sekitar 269 persen. ${ }^{19}$ Hal tersebut dijelaskan dalam bentuk tabel di bawah ini:

TABEL KELEBIHAN HUNIAN NARAPIDANA KURUN WAKTU 5 TAHUN (Tahun 2015 s.d. 2019)

\begin{tabular}{|c|c|c|c|c|}
\hline NO. & TAHUN & PENGHUNI & KAPASITAS & OVER KAPASITAS \\
\hline 1. & 2015 & 21,317 & 12,065 & $9,252=177 \%$ \\
\hline 2. & 2016 & 24,939 & 12,065 & $12,874=207 \%$ \\
\hline 3. & 2017 & 29,615 & 12,065 & $17,550=245 \%$ \\
\hline 4. & 2018 & 33,611 & 12,065 & $21,546=279 \%$ \\
\hline 5. & 2019 & 34,517 & 12,065 & $22,452=286 \%$ \\
\hline
\end{tabular}

Melihat data tersebut di atas bahwa faktanya setiap tahun selalu terjadi over kapasitas, jumlah penghuni setiap tahun mengalami penambahan/peningkatan yang memunculkan ketidakadilan di tengah masyarakat, khususnya para tahanan dan narapidana. Hak-hak dari para tahanan dan narapidana menjadi tidak terealisasi, hal tersebut dapat dibuktikan dari keadaan tersebut yang mengakibatkan sulitnya para warga binaan pemasyarakatan ( para tahanan dan narapidana ) untuk beristirahat dan beraktifitas dan mengakibatkan terganggunya hak-hak warga binaan berupa yang pertama hak kesehatan, dimana para warga binaan pemasyarakatan seharusnya memiliki hak untuk mendapatan pemeriksaan 1 (satu) kali dalam 1 (satu) bulan, namun dikarenakan jumlah tenaga medis yang tidak sebanding dengan jumlah warga binaan pemasyarakatan maka hak tersebut sering menjadi tidak terlaksana. Paling mirisnya, over kapasitas dari lembaga pemasyarakatan ini, mengakibatkan satu sel yang berukuran kecil dapat dihuni oleh puluhan orang.

Kondisi tersebut di atas banyak terjadi di lembaga pemasyarakatan, berapa banyak anggaran yang harus dikeluarkan oleh negara untuk menambah kapasitas bangunan atau

\footnotetext{
${ }^{18}$ R. Ahmad Soemadi Praja dan Romli Atmasasmita, Sistem Pemasyarakatan Di Indonesia, (Bandung: Bina Cipta, 1979), 115 .

${ }^{19}$ Dewa Putu Gede, Kepala Kantor Wilayah Kementrian Hukum dan HAM (Kemenkumham) Sumatera Utara, "Lapas dan Rutan di Sumut Overkapasitas Hingga 269 Persen", News.okezone.com, diakses pada hari Jumat tanggal 18 Oktober 2019 Pukul o8.0o WIB.
} 
membangun Lapas/Rutan yang baru. Keadaan tersebut memberi peluang ruang baru bagi para terpidana untuk masuk mengingat semakin tingginya tingkat kriminalisasi sehingga kebijakan social (social policy) yang diartikan sebagai usaha yang rasional untuk mencapai kesejahteraan masyarakat dan perlindungannya tidak terpenuhi. ${ }^{20}$

Sistem pemidanaan yang ada sudah tidak efektif dalam upaya menekan tingginya angka kriminalitas yang ujung-ujungnya mengakibatkan terjadinya kelebihan hunian di lembaga pemasyarakatan, sehingga muncullah wacana mediasi penal sebagai bagian dari metode restorative justice. Perkembangan konsep peradilan pidana di Indonesia yang bersifat konvensional hanya berfokus pada ranah pemidanaan dan penghukuman bagi pelaku tindak pidana sehingga belum maksimal menyentuh kepentingan masyarakat dan/atau korban yang dirugikan akibat tindak pidana yang telah dilakukan oleh pelaku baik secara perseorangan maupun penyertaan.

Sejalan dengan pandangan Muhaimin ${ }^{21}$ bahwa "penyelesaian tindak pidana biasa bermotif ringan dapat ditempuh dengan mediasi penal disebut pendekatan Restorative Justice, yaitu menitikberatkan pada adanya partisipasi langsung pelaku, korban dan masyarakat dengan memaknai tindak pidana pada dasarnya adalah serangan terhadap individu dan masyarakat serta hubungan kemasyarakatan, maka keadilan dimaknai sebagai proses pencarian penyelesaian masalah yang terjadi atas suatu perkara pidana biasa bermotif ringan dengan keterlibatan korban, masyarakat dan pelaku menjadi penting dalam usaha perbaikan, rekonsiliasi dan penjaminan keberlangsungan usaha perbaikan tersebut."

Menurut July Esther bahwa penerapan restorative justice tersebut diwujudkan dalam sebuah perjanjian perdamaian yang memuat kesepakatan restitusi dan keterlibatan pelaku dalam pemulihan fisik dan non fisik korban yang diketahui oleh kedua belah pihak dan disaksikan oleh kepolisian. Perjanjian perdamaian tersebut menjadi salah satu dasar pertimbangan kepolisian untuk tidak meneruskan dan melimpahkan semua kasus tindak pidana ke kejaksaan. Penerapan restorative justice menjadi sangat penting karena menghormati hak-hak korban tindak pidana dan meminimalisir meningkatnya kasus tindak pidana. Penerapan restorative justice tersebut sangat baik dilakukan pada tingkat penyidikan di kepolisian. ${ }^{22}$

Bentuk pendekatan Restorative Justice menurut Vira Zemlyanska sebagaimana dikutip oleh Trisno Raharjo dapat digolongkan menjadi tiga kategori:

1. Victim-Offender Mediation (VOM)

VOM memberikan jalan kepada pelaku kejahatan untuk bertemu dan berdialog dengan korban kejahatan, dengan dibantu oleh mediator yang terlatih, bahkan membuat perjanjian tertulis dengan rencana selanjutnya setelah restitusi disepakati. VOM bertujuan untuk mencapau kesepakatan melalui penyembuhan korban, pertanggungjawaban si pelaku atas kejahatannya dan pengembalian kerugian.

2. Victim-Offender Conferences (VOC)

VOC memberikan jalan kepada pelaku kejahatan untuk bertemu dan berdialog dengan korban kejahatan. VOC melibatkan banyak orang yang hadir: orang muda diundang, orang yang memiliki hubungan dekat dengan pelaku, korban dan para pendukungnya, atau yang lain yang dilukai oleh pelaku, dengan dipandu oleh seorang fasilitator semua

\footnotetext{
${ }^{20}$ Barda Nawawi Arief, Kebijakan Hukum Pidana, (Jakarta: Kencana Prenada Media Group, 2011), 28.

${ }^{21}$ Muhaimin, "Restoratif Justice Dalam Penyelesaian Tindak Pidana Ringan (Restorative Justice in Settlement of Minor Offences)", Jurnal Penelitian Hukum De Jure Vol. 19 No. 2, Juni 2019: 185-206.

${ }^{22}$ July Esther, "Tindak Pidana Perdagangan Orang Dalam Perspektif Tindak Pidana Transnasional Yang Terorganisasi”, Disertasi, (Surabaya: Program Doktor Program Studi Ilmu Hukum Fakultas Hukum Universitas Airlangga, 2013), 234.
} 
peserta menunjukkan kerugian yang mereka derita dan akibat dari kejahatan yang dilakukan oleh pelaku.

3. Circles

Circles mengundang para pihak yang berkepentingan dalam masyarakat untuk turut serta. Para peserta duduk secara melingkar, dengan saling berdiskusi sesuai dengan putaran jarum jam sampai para pihak menemukan resolusi. ${ }^{23}$

Melihat eksistensi mediasi penal sebagai salah satu alternatif penyelesaian perkara dibidang hukum pidana melalui restitusi dalam proses pidana yang menunjukkan bahwa perbedaan antara hukum pidana dan perdata tidak begitu besar dan perbedaan itu dapat dikesampingkan mengingat tujuan dari hukum itu sendiri memberikan "kemanfaatan" sehingga Hukum Pidana kemudian mengarah, lahir, tumbuh dan berkembang menjadi bagian dari hukum Publik seperti dikenal sekarang ini. Eksistensinya penyelesaian perkara di luar pengadilan melalui "mediasi penal" merupakan dimensi baru dikaji dari aspek teoritis dan praktik yang pada harapannya mediasi penal akan berkorelasi dengan pencapaian dunia peradilan sejati.

Mediasi formal di pengadilan juga mempunyai kelebihan yaitu kesepakatan yang dicapai mempunyai kekuatan eksekutorial sama seperti putusan hakim dan akta perdamaian sebagai akta yang memuat isi kesepakatan perdamaian dan putusan hakim yang menguatkan kesepakatan perdamaian tersebut tidak tunduk pada upaya hukum biasa maupun luar biasa. ${ }^{24}$ Jadi mediasi mempunyai kekuatan yang luar biasa yaitu eksekutorial dan final (tidak bisa dibanding dan kasasi). Mediasi di pengadilan juga dapat dilakukan untuk sengketa yang berada dalam tingkat banding, kasasi, dan peninjauan kembali. ${ }^{25}$

Kebaikan lain dari konsep mediasi ini ternyata berkorelasi dengan efisiensi waktu di pengadilan yang hanya memakan waktu sekitar 2 (bulan) sejak penunjukan mediator sampai mencapai kesepakatan. ${ }^{26}$ Mediasi komunitas bisa lebih cepat dalam menyelesaikan sengketa sesuai dengan keinginan para pihak yang tidak ingin berlarut-larut hingga bisa merenggangkan hubungan. Bandingkan dengan proses litigasi yang membutuhkan waktu 6 (enam) bulan untuk menyelesaikan kasus di tingkat pertama (Pengadilan Negeri). Belum lagi kalau sebuah kasus mencapai tingkat banding, kasasi, atau peninjauan kembali, kasus tersebut memakan waktu sampai 7-12 tahun. ${ }^{27}$ Dengan sedikitnya waktu yang digunakan, otomatis biaya yang dikeluarkan juga sedikit. Prosedur mediasi juga sederhana seperti bernegosiasi dalam kehidupan sehari-hari, tanpa terminologi atau prosedur yang tidak dimengerti orang awam. Dengan sifat mediasi yang final dan sedikitnya waktu yang dibutuhkan untuk menyelesaikan sebuah kasus, maka mediasi juga berguna untuk mengatasi masalah penumpukan perkara yang terjadi di Mahkamah Agung Republik Indonesia.

Supeno berpandangan bahwa "dalam model keadilan restoratif, hukuman terhadap pelaku tetap ada, tetapi hukuman itu diletakkan sebagai bagian dari proses pendidikan, bukan sebagai balas dendam dan pemidanaan. Hukuman dalam rangka proses pendidikan bukanlah hukuman yang melemahkan semangat hidup apalagi mematikan masa depan anak, tetapi justru harus berfungsi mencerahkan secara moral dan mendewasakan sebagai pribadi yang utuh." ${ }^{28}$

\footnotetext{
${ }^{23}$ Trisno Raharjo, Op.cit., 30-34.

${ }^{24}$ Pasal 1 ayat 2 PerMA Nomor 1 Tahun 2008 tentang Prosedur Mediasi di Pengadilan.

${ }^{25}$ Pasal 21 PerMA Nomor 1 Tahun 2008 tentang Prosedur Mediasi di Pengadilan.

${ }^{26}$ Pasal 13 ayat 3 PerMA Nomor 1 Tahun 2008 tentang Prosedur Mediasi di Pengadilan.

${ }^{27}$ M. Yahya Harahap, Hukum Acara Perdata, (Jakarta: Sinar Grafika, 2005), 154.

${ }^{28}$ Hadi Supeno, Kriminalisasi Anak: Tawaran Gagasan Radikal Peradilan Anak Tanpa Pemidanaan, (Jakarta: Gramedia Pustaka Utama, 2010), 222.
} 
Demikian pula Yuliana menyatakan bahwa khusus Penanganan Anak sebagai pelaku tindak pidana penyalahgunaan narkoba, maka Rehabilitasi menjadi pendekatan Humanis dalam memberikan perlindungan khusus bagi anak yang berkonflik dengan hukum. Namun pendekatan humanis ini seyogyanya tidak mengesampingkan penegakan hukum dengan tetap menempatkan anak pada Lembaga Pembinaan Khusus Anak (LPKA). ${ }^{29}$ Namun pelaksanaan mediasi penal yang dimulai dari tahapan penyidikan kepolisian memiliki hambatan yang sering menjadi kendala dalam penerapannya. Faktor yang menghambat berjalannya Mediasi Penal melalui pendekatan Restorative Justice sebagai upaya meminimalisir kelebihan hunian (over capacity) yang dimulai dari tahapan penyidikan kepolisian diantaranya adalah:

1. Faktor perundang-undangan, yaitu belum adanya undang-undang yang mengatur upaya yang harus dilakukan apabila terjadi penolakan perdamaian oleh korban atau keluarga korban.

2. Faktor penegak hukum, yaitu secara kuantitas masih terbatasnya jumlah anggota dalam menangani tindak pidana dan secara kualitas masih kurangnya pengetahuan dan keterampilan penyidik dalam menerapkan perdamaian dalam penyelesaian tindak pidana.

3. Faktor masyarakat, khususnya korban dan keluarga korban menolak perdamaian dan menginginkan agar pelaku tindak pidana sebagai pelaku tindak pidana tetap diproses secara hukum.

\section{D.Kesimpulan}

Berdasarkan pembahasan dan analisis yang telah dipaparkan, maka peran "Mediasi Penal" melalui pendekatan "Restorative Justice" sebagai upaya meminimalisir kelebihan hunian (over capacity) sangat jelas diperlukan. Berkaca dari uraian yang telah di paparkan penulis bahwa setiap tahun selalu terjadi kelebihan hunian di hampir seluruh hunian lembaga pemasyarakatan yang tentunya menghadirkan banyak permasalahan, baik antara korban dan pelaku bahkan pula terhadap kualitas negara.

Mediasi Penal sangat dibutuhkan untuk menjadi penengah proses penyelesaian dan penanganan hukum berupa perdamaian antara pelaku tindak pidana dan atau keluarganya dengan korban tindak pidana dan atau keluarganya. Namun terlebih dahulu dimulai dari tahap penyidikan di kepolisian dengan memilah jenis tindak pidana yang terjadi, dalam hal ini dapat dicontohkan tindak pidana ringan dan tindak pidana dengan ancaman pidana penjara tidak lebih dari 5 (lima) tahun. Hal ini bertujuan untuk pembaharuan pemahaman mengenai perkara di luar pengadilan melalui pendekatan "restorative justice" dapat mewujudkan harapan pencapaian dunia peradilan sejati.

Adapun rekomendasi yang dapat diberikan pada penelitian ini adalah sebagai berikut:

1. Pemerintah agar segera merevisi KUHP dan KUHAP agar sistem Restorative Justice dan mediasi penal dapat segera dilaksanakan dalam sistem peradilan pidana di Indonesia dengan aturan hukum yang pasti. Agar kedepannya permasalahan pidana mendapat tempat di mata pencari kebenaran, karena saat ini sistem hukum di Indonesia bobrok dan sulit bagi yang mencari keadilan dan kepastian hukum yang berlandaskan pada asas peradilan cepat, murah, dan sebagai upaya meminimalisir berkas perkara yang menumpuk di tingkat pertama (Pengadilan Tingkat Pertama) sampai tingkat Mahkamah Agung, yang mana setiap tahun banyak kasus yang menjadi pekerjaan rumah bagi Mahkamah Agung.

\footnotetext{
${ }^{29}$ Yuliana Primawardani, "Pendekatan Humanis Dalam Penanganan Anak Pelaku Tindak Pidana Penyalahgunaan Narkoba Studi Kasus Di Provinsi Sulawesi Selatan,” Jurnal Penelitian Hukum De Jure Vol. 17 No.4 (2017): 411-427.
} 
2. Aparat penegak hukum disarankan untuk terus meningkatkan profesionalisme dan kapasitas sebagai pelaksana proses penegakan hukum perdamaian antara pihak-pihak yang terlibat dalam tindak pidana, dengan cara terus mengasah potensi yaitu mengikuti berbagai pelatihan untuk menyesuaikan diri pada perkembangan teknik perdamaian guna meminimalisir kelebihan hunian (over capacity).

\section{Daftar Pustaka}

Arief. Barda Nawawi. Kebijakan Legislatif Dalam Penanggulangan Kejahatan Dengan Pidana Penjara. Semarang: Badan Penerbit Universitas Diponegoro Semarang, 2000. . Kebijakan Hukum Pidana. Jakarta: Kencana Prenada Media Group, 2011. Mediasi Penal Penyelesaian Perkara Pidana Di Luar Pengadilan. Semarang: Pustaka Magister, 2012.

Dewi. DS. dan Fatahillah A. Syukur. Mediasi Penal: Penerapan Restorative Juctice Di Pengadilan Anak Indonesia. Depok: Indie Pro Publishing, 2011.

Harahap. M. Yahya. Hukum Acara Perdata. Jakarta: Sinar Grafika, 2005.

Mulyadi. Lilik. Mediasi Penal Dalam Sistem Peradilan Pidana Indonesia. Bandung: Alumni, 2015. Praja. R. Ahmad Seomadi dan Romli Atmasasmita. Sistem Pemasyarakatan di Indonesia. Bandung: Bina Cipta, 1979.

Raharjo, Trisno. Mediasi Pidana dalam Sistem Peradilan Pidana-Suatu Kajian Perbandingan dan Penerapannya di Indonesia. Yogyakarta: Buku Litera, 2011.

Rahardjo. Satjipto. Bunga Rampai Permasalahan dalam Sistem Peradilan Pidana. Jakarta: Pusat Pelayanan Keadilan dan Pengabdian Huku, 1998.

Setiadi. Tolib. Pokok-pokok Hukum Penitentier Indonesia. Jakarta: Alfabeta, 2010.

Supeno. Hadi. Kriminalisasi Anak: Tawaran gagasan Radikal Peradilan Anak Tanpa Pemidanaan. Jakarta: Gramedia Pustaka Utama, 2010.

Waluyo. Bambang. Pidana dan Pemidanaan. Jakarta: Sinar Grafika, 2008.

Artikel Ilmiah dan Website

Bayu Ardian Aminullah dan Barda Nawawi Arief, "Penerapan Mediasi Penal Dengan Pendekatan Restorative Justice Dalam Upaya Penanggulangan Kejahatan Di Indonesia", Jurnal Meta-Yuridis Vol 3, No 1, 2020.

Esther. July. "Tindak Pidana Perdagangan Orang Dalam Perspektif Tindak Pidana Transnasional Yang Terorganisasi”, Disertasi, Program Doktor Program Studi Ilmu Hukum Fakultas Hukum Universitas Airlangga, Surabaya, 2013.

Muhaimin, "Restoratif Justice Dalam Penyelesaian Tindak Pidana Ringan (Restorative Justice in Settlement of Minor Offences)", Jurnal Penelitian Hukum De Jure Vol. 19 No. 2, Juni 2019.

Raden Muhammad Rizki Hidayatullah, "Faktor Penyebab Dan Upaya Penyelesaian Permasalahan Kepadatan Penghuni Lembaga Pemasyarakatan Di Indonesia", Borneo Law Review Journal Volume 4 No. 1, 2020.

Simamora, Janpatar dan Naibaho, Bintang ME, Statutory of The Republic of Indonesia Witness As a Government Institution Implementing Country's Power in The Indonesian State Concerns System, Proceedings of the First Nommensen International Conference on Creativity \& Technology, NICCT, 20-21 September 2019, Medan, North Sumatera, Indonesia.

Yuliana Primawardani, "Pendekatan Humanis Dalam Penanganan Anak Pelaku Tindak Pidana Penyalahgunaan Narkoba Studi Kasus Di Provinsi Sulawesi Selatan,” Jurnal Penelitian Hukum De Jure Vol. 17 No.4, Desember 2017. 
Nommensen Journal of Legal Opinion (NJLO)

Jurnal Magister Hukum Program Pascasarjana Universitas HKBP Nommensen

Volume or Nomor o1 Juli 2020 Halaman. 27-37 e-ISSN: 2723-164X p-ISSN: 2722-9858

http://ejournal.uhn.ac.id/index.php/opinion

Kakanwil. 2015-2019. “Over kapasitas LP Sumatera Utara”,http:// News.okezone.com, diakses pada tanggal 28 Oktober 2019.

Manan, Bagir. 200o. "Perlu Ada Pendamai di Luar Pengadilan", Media Indonesia, diakses pada tanggal 28 Oktober 2019.

Gede. Dewa Putu, Kepala Kantor Wilayah Kementrian Hukum dan HAM (Kemenkumham) Sumatera Utara, "Lapas dan Rutan di Sumut Over Kapasitas Hingga 269 Persen", News.okezone.com, 2019. 